\title{
DINAMIKA PEMAHAMAN KONSEP SISWA SMP PADA MATERI ENERGI NORMALIZED GAIN VERSUS NORMALIZED LOSS
}

\author{
M. Arif Mahdiannur ${ }^{1)}$, Mohamad Nur' ${ }^{2}$, Z. A. Imam Supardi ${ }^{3)}$ \\ ${ }^{1)}$ Mahasiswa Program Studi Pendidikan Sains, Program Pascasarjana Universitas Negeri Surabaya \\ ${ }^{2), 3)}$ Dosen Pascasarjana Prodi Pendidikan Sains Univesrtitas Negeri Surabaya \\ E-mail: mahdiannur1@gmail.com
}

\begin{abstract}
This article discusses about the dynamic of Junior High School students' conceptual understanding on energy due to an intervention. The key indicators to see these dynamic of conceptual understanding, i.e. by comparing the normalized gain ( $N$ gain) score with the normalized loss $(L)$ score. This study employed a design experiment and conducted at SMPN 1 Tanah Grogot, Paser Regency, East Kalimantan in the First Semester Academic Year 2015/2016. Subject research were 30 students from the 7th grade. The data were obtained from results of students' conceptual understanding tests about energy (pretest and posttest). The results of this study showed that: (1) students who got low $N$-gain score tend to have a loss; and generally $N$-gain $>$ $L$, that mean the intervention could promote students to understand substantive concepts on energy topics. Based on these results despite some limitation, could be concluded that students' conceptual understanding and students' conception change influenced by the intervention and reinforced the conceptual change theory especially on the knowledge-as-elements perspectives.
\end{abstract}

\section{Keywords: Conceptual Understanding, Intervention, Normalized Gain, Normalized Loss, Energy}

\begin{abstract}
Abstrak: Artikel ini membahas mengenai dinamika pemahaman konsep siswa SMP pada materi energi akibat adanya intervensi. Indikator kunci untuk melihat dinamika pemahaman konsep tersebut, yaitu dengan membandingkan score normalized gain $(N$ gain) dengan score normalized loss $(L)$. Studi ini menggunakan design experiment dan dilakukan di SMPN 1 Tanah Grogot, Kab. Paser, Kalimantan Timur pada Semester Ganjil Tahun Pembelajaran 2015/2016. Subjek penelitian ini adalah 30 orang siswa kelas VII. Data diperoleh dari hasil tes pemahaman konsep siswa tentang energi (pretest dan posttest). Hasil studi menunjukkan bahwa: (1) siswa yang memperoleh skor $N$-gain rendah akan cenderung mengalami loss; dan (2) secara umum $N$-gain $>L$, yang berarti intervensi dapat mengenalkan siswa untuk memahami konsep-konsep substantif pada topik energi. Berdasarkan hasil-hasil tersebut meskipun terdapat beberapa limitasi, dapat disimpulkan bahwa pemahaman konsep dan perubahan konsepsi siswa dipengaruhi oleh intervensi serta menguatkan teori perubahan konsep khususnya pada perspektif pengetahuan seperti elemen.
\end{abstract}

Kata kunci: Pemahaman Konsep, Intervensi, Normalized Gain, Normalized Loss, Energi.

\section{PENDAHULUAN}

Pendidikan IPA (fisika) memiliki tujuan utama untuk mengembangkan kompetensi siswa dalam memecahkan persoalan di dunia nyata dengan mengaplikasikan konsep dan teori IPA (fisika) sehingga dapat membantu siswa menjadi masyarakat yang dapat berpikir luas, sadar sains (ilmu), dan sadar ilmiah (Niss, 2012; Rusli, 2012; Coca \& Slisko, 2013; Scott et al., 2013). Siswa penting untuk menguasai pengetahuan replikatif dan pengetahuan aplikatif, tetapi siswa masih mengalami transisi dalam proses pemecahan masalah sehingga perubahan utama yang diharapkan dari pendidikan IPA (fisika), yaitu mampu mengubah pandangan siswa terhadap dunia (Čančula et al., 2015; Lasry et al., 2014) belum terwujud seluruhnya. Salah satu pertanyaan fundamental dalam bidang pendidikan IPA saat ini adalah "bagaimana kita belajar?” Berbagai upaya telah dilakukan untuk menjawab pertanyaan tersebut, di antaranya dengan meneliti perkembangan pemahaman konsep siswa. Banyak hasil penelitian yang mengungkapkan adanya peningkatan pemahaman konsep setelah intervensi tertentu, tetapi ada juga yang tidak. Hal tersebut menunjukkan bahwa suatu intervensi yang dilakukan tidak selalu memberikan hasil yang cukup signifikan dan kebingungan siswa tidak langsung terkait dengan performa awal, konfidensi, efikasi-diri, perbedaan guru, sekolah, populasi siswa, serta beberapa variasi dalam pedagogi dan sistem pendidikan (Dowd, 2012; Fraser et al., 2014; Clark et al., 2014). Para guru juga belum memberikan dampak bagi pemikiran siswa tentang dunia nyata, mutu pendidikan rendah, dan masih berorientasi pada nilai (Redish, 1994).

Permasalahan terkait dengan konsep siswa juga ditandai dengan cepatnya siswa untuk melupakan konsep-konsep yang baru dipelajarinya dan para siswa mengalami kesulitan untuk menghubungkan informasi- 
informasi baru ke dalam struktur kognitifnya. Hal tersebut disebabkan oleh miskonsepsi, konsep abstrak, penalaran intuitif, dan epistemological framing dari tiga praktik fundamental pada tiga tipe pengetahuan secara ilmiah dan interaksinya secara non-formal dengan lingkungan (Kelly \& Sezen, 2010; Taber, 2010, 2011; Kind, 2013b; Redish, 2014). Pemahaman konsep siswa merupakan hal yang paling pokok untuk menentukan bagaimana siswa dapat mengubah pandangannya terhadap dunia dan memaknai proses belajar dan pengetahuan yang telah dikonstruksi dari mediasi artefak kependidikan secara dialektis.

Penentuan elemen-elemen pemahaman konsep menjadi penting agar dapat ditentukan definisi operasio-nalnya sehingga memudahkan dalam menyusun instrumen serta asesmen dan evaluasinya. Penentuan elemen-elemen pemahaman konsep sangat berkaitan dengan taksonomi pendidikan, khususnya pada ranah kognitif. Salah satu taksonomi pendidikan pada ranah kognitif yang paling dikenal dan paling banyak digunakan adalah taksonomi Bloom, baik yang sebelum revisi maupun yang telah direvisi. Taksonomi Bloom sendiri hanya mengacu pada dimensi pengetahuan umum dan tidak secara langsung terkait dengan bidang ilmu tertentu dan dapat disimplifikasi menjadi tiga kategori, yaitu spesifikasi pengetahuan, interpretasi pengetahuan dan menggambar-kan inferensi, serta menerapkan pengetahuan ke situasi yang berbeda (Delgado, 2015; Singh \& Rosengrant, 2003). Snir dan koleganya mengatakan bahwa level konseptual terdiri atas konsep dan teori (Delgado, 2015). Konsep dalam sains sendiri terbagi menjadi dua, yaitu: (1) konsep substantif; dan (2) konsep bukti atau concept of evidence (Gott \& Duggan, 1995).

Berdasarkan pendapat tersebut maka jelas bahwa pemahaman konsep dalam sains harus merujuk pada konsep-konsep substantif, yakni fakta, hukum, konsep, prinsip, dan teori dalam sains (Gott \& Duggan, 1995). Definisi pemahaman konsep dalam pendidikan sains adalah inferensi secara bermakna dengan mengingat pengetahuan tentang konsep substantif dalam suatu cara yang sadar dan mengintegrasikan pengetahuan tersebut dengan konsep substantif lain yang berhubungan, dapat mentransfer dan mengaplikasikan konsep substantif, dapat menalar secara analogi tentang suatu konsep substantif, serta dapat menalar secara lokal dan umum tentang suatu konsep substantif tersebut (Gott \& Duggan, 1995; Wiggins \& McTighe, 2005; Anderson \& Schönborn, 2008). Berdasarkan pengertian tersebut maka elemen-elemen pemahaman konsep dalam studi ini dipilih menurut TIMSS Advanced bidang fisika membagi ranah kognitif menjadi tiga macam, yakni: (1) mengetahui (knowing); (2) menerapkan (applying); dan (3) menalar (reasoning) (Garden et al., 2006). Pembagian kerangka sains dalam ranah kognitif menjadi tiga elemen menurut TIMSS tersebut juga berlaku untuk taksonomi Bloom revisi dan simplifikasi taksonomi Bloom (Kind, 2013a; Singh \& Rosengrant, 2003).

Salah satu fokus dalam sains dan teknik adalah crosscutting concept, yaitu jembatan yang menyatukan studi dalam bidang sains dan teknik melalui suatu penerapan umum secara lintas disiplin atau disebut juga penyatuan tema-tema (National Research Council [NRC], 2012). Materi energi boleh dibilang merupakan satu-satunya crosscutting concept yang melintasi berbagai bidang ilmu. Energi dan hal-hal yang terkait merupakan bagian dari pengalaman dan bahasa seharihari siswa (Lee \& Liu, 2010). Pemahaman konsep jelas terkait dengan crosscutting concept dan menjadi menarik untuk diteliti karena konsep energi telah lama dipelajari oleh siswa dan telah menjadi bagian dalam kesehariannya. Perkembangan konsep energi secara ilmiah sendiri sangat kompleks dan sangat penting bagi kita untuk menyadari jika di dalam fisika saat ini kita tidak mengetahui apa itu energi, serta banyak ahli fisika yang mengemukakan kesulitannya untuk mendefinisikan apa itu energi (Coelho, 2009, 2014; Constantinou \& Papadouris, 2012). Materi energi merupakan topik yang menantang dari sekolah dasar hingga Perguruan Tinggi dan menjadi salah satu pusat dalam organisasi dan prinsip sains (Ding et al., 2013; Lee \& Liu, 2010). Materi energi dalam artikel ini merujuk pada 4 'konsep dasar' energi dari perspektif fisika, yaitu: (1) konservasi energi; (2) transfer energi; (3) transformasi energi; dan (4) degradasi energi atau sumber-sumber energi (Duit, 2014). Keseluruhan lingkup konsep energi tersebut merupakan pertimbangan untuk membelajarkan siswa tentang energi serta mengukur dan mengevaluasi pemahaman konsep siswa tentang energi.

Tujuan utama pendidikan sains seperti yang telah disebutkan sebelumnya, yaitu untuk membelajarkan siswa tentang kesadaran akan pentingnya sains dan membantu siswa agar mampu memecahkan masalah. Fokus artikel ini adalah pada perkembangan konsep akademik dalam proses belajar-mengajar (PBM) formal. Hal tersebut dilandaskan pada teori Vygotsky yang mengemukakan bahwa ada dua tipe konsep, yaitu: (1) konsep yang dikembangkan secara spontan oleh seseorang tanpa pendidikan formal; dan (2) konsep yang dikembangkan dari proses pendidikan formal yang memungkinkan adanya interaksi (Taber, 2010, 2011). Konstruktivisme, teori pemrosesan informasi, dan teori perkembangan moral juga memberikan dasar yang penting, yaitu: (1) setiap orang mengonstruksi pengetahuannya sendiri; (2) proses-proses internal seseorang berakar pada interaksi dengan orang lain secara dialektis sebagai basis internalisasi; (3) siswa akan memproses suatu informasi berdasarkan atensi, 
memori, berpikir, dan proses-proses kognitif lainnya; dan (4) sistem lingkungan berpengaruh terhadap perkembangan anak yang fokus pada aturan dan konvensi dari interaksi antara orang-orang dalam tiga ranah, yakni: kognitif, perilaku, dan emosional (Sternberg \& Williams, 2010; Santrock, 2011; Murphy, 2012). Oleh karena itu, artikel ini berusaha untuk memaparkan secara singkat hasil penyelidikan mengenai dinamika pemahaman konsep siswa yang dimediasi oleh interaksi selama proses pembelajaran formal berlangsung.

\section{METODE PENELITIAN}

Studi yang kami lakukan adalah "design experiment." Istilah eksperimen tersebut jangan diasosiasikan dengan jenis penelitian eksperimental (Gravemeijer \& Cobb, 2013). Definisi "design experiment" adalah suatu penyelidikan yang cenderung pragmatis dan memiliki orientasi secara teoretis untuk mencoba, mengelaborasi, dan meningkatkan desain instruksional atau teori instruksional lokal dan mengembangkan sebuah pemahaman bagaimana hal tersebut bekerja (Gravemeijer \& Cobb, 2013; Cobb et al., 2003). Design experiment dipilih karena dalam studi ini kami tidak dapat melakukan uji coba secara acak (randomized trials) (Kelly et al., 2008). Istilah design experiments juga diidentifikasi oleh para ahli dengan nama lain seperti "design research" dan "developmental research," tetapi istilah "developmental research" bisa menimbulkan kerancuan konotasi dengan istilah dalam psikologi perkembangan dan perkembangan konsep matematika siswa dalam penelitian pendidikan matematika (Coffin, 2014; Bakker 2004). Design experiment saat ini dimasukkan dalam kelompok atau pendekatan "design-based research" (DBR) (Wang \& Hannafin, 2005; Juuti \& Lavonen, 2012), tetapi dalam artikel ini kami tetap mempertahankan istilah design experiment karena langkah-langkah yang kami gunakan, merujuk dan mengadaptasi fase-fase design experiment menurut Gravemeijer \& Cobb (2013). Fase-fase tersebut juga digabungkan dengan desain penelitian umum menurut Ketpichainarong et al. (2010).

Intervensi yang dilakukan selama fase classroom tryout, yaitu penerapan model pembelajaran inkuiri induktif terbimbing (IIT) beserta artefak kependidikan yang mendukung proses belajar siswa pada materi energi. Subjek penelitian yang dilibatkan dalam studi ini adalah 30 orang siswa kelas VII C. Tempat penelitian dilakukan di SMP Negeri 1 Tanah Grogot, Kab. Paser, Provinsi Kalimantan Timur. Penelitian ini dilakukan pada Semester Ganjil, Tahun Pembelajaran 2015/2016. Teknik pengumpulan data berupa tes pemahaman konsep dengan menggunakan instrumen Tes Pemahaman Konsep pretest dan posttest (Instrumen 1a dan 1b). Instrumen tersebut dipilih dari soal-soal tentang materi energi yang telah dikembangkan oleh para ahli seperti soal-soal AAAS Science Assessment Project 2061, Energy and Momentum Conceptual Survey (EMCS) oleh Rosengrant dan Singh, serta Conceptual Understanding Test about Energy Concept oleh Kocakulah dan koleganya. Soal-soal yang tercantum dalam Tes Pemahaman Konsep (pretest dan posttest) dipilih dari ketiga macam instrumen standar tersebut yang disesuaikan dengan tiga elemen pemahaman konsep, yaitu elemen mengetahui (7 soal), menerapkan (5 soal), dan menalar (3 soal). Seluruh soal tersebut telah kami konsultasikan dengan tiga orang pakar terkait relevansi dan konsistensinya.

Pemahaman konsep selalu diukur secara tidak langsung melalui tes. Instrumen 1a (pretest) dan Instrumen $1 \mathrm{~b}$ (posttest) berbentuk pilihan ganda dengan empat macam pilihan jawaban. Pedoman penskoran pada penelitian ini dengan tanpa koreksi berdasarkan Kunci yang telah ditetapkan sebelumnya atau merujuk pada penilaian berdasarkan acuan patokan. Dinamika pemahaman siswa dalam studi ini didasarkan pada perbandingan hasil nilai normalized gain ( $N$-gain) dan normalized loss $(L)$ siswa. $N$-gain adalah probabilitas kondisional statistik yang menyatakan seberapa banyak kekeliruan siswa yang berhasil diperbaiki selama proses pembelajaran (Bao, 2008; Smith et al., 2014; Stewart \& Stewart, 2010). N-gain menurut Hake (1998) dirumuskan sebagai berikut:

$N-$ gain $=\frac{S_{\text {post }}-S_{\text {pre }}}{S_{\max }-S_{\text {pre }}}$

dengan,

$S_{\text {pre }}=$ skor pretest

$S_{\text {post }}=$ skor posttest

$S_{\max }=$ skor maksimum

Persamaan 1 tersebut adalah $N$-gain individual dan rerata $\mathrm{N}$-gain dihitung dengan membagi jumlah $\mathrm{N}$-gain tiap individu dengan banyaknya individu (Bao, 2006; Smith et al., 2014). Interpretasi $N$-gain disajikan pada Tabel 1.

Tabel 1. Interpretasi nilai $N$-gain

\begin{tabular}{|l|l|}
\hline Skor $\boldsymbol{N}$-gain & Klasifikasi \\
\hline$N$-gain $\geq 0,7$ & Tinggi \\
\hline $0,7>N$-gain $\geq 0,3$ & Sedang \\
\hline$N$-gain $<0,3$ & Rendah \\
\hline
\end{tabular}

(Sumber: Hake, 1998)

Persamaan 1 tersebut mengabaikan aspek retensi dan loss yang terjadi pada siswa selama masa pembelajaran. Normalized loss $(L)$ didefinisikan sebagai kemungkinan perubahan jawaban benar pada pretest, menjadi jawaban salah pada posttest (Dellwo, 2010). $L$ tersebut merujuk pada kehilangan potensial yang merupakan cerminan 
dari proses transisi yang terjadi pada diri siswa. Siswa dikatakan mengalami loss jika nilai $L>0$ (Miller et al., 2010). Rumus $L$ pada penelitian ini menggunakan versi Miller et al. (2010) karena tes pemahaman konsep berbentuk pilihan ganda. Rumus $L$ tersebut diformulasikan sebagai berikut:

$$
L=\frac{R W}{R R+R W}
$$

dengan,

$\mathrm{RR}=$ jawaban pada pretest benar dan jawaban pada posttest benar.

$\mathrm{RW}=$ jawaban pada pretest benar dan jawaban pada posttest salah.

\section{HASIL PENELITIAN DAN DISKUSI}

\section{A. Hasil Penelitian}

Hasil sebaran $\mathrm{N}$-gain individu siswa dari proses classroom tryout, disajikan pada Gambar 1.

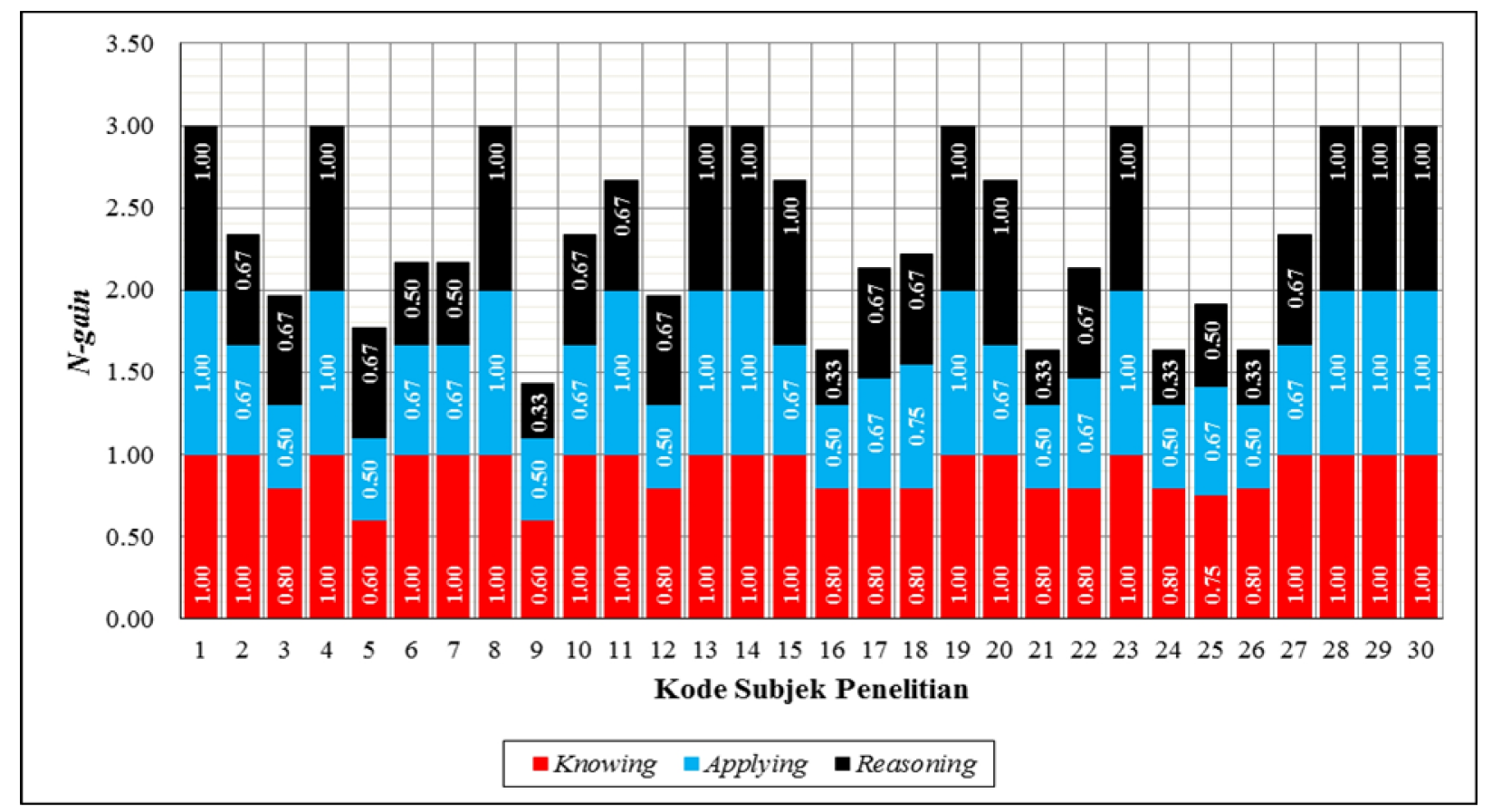

Gambar 1 Grafik sebaran $N$-gain siswa pada tiap elemen pemahaman konsep

Berdasarkan sebaran $N$-gain pada tiap elemen pemahaman konsep dari Gambar 1 diperoleh informasi, yakni: (1) $\mathrm{N}$-gain tertinggi elemen mengetahui (knowing), menerapkan (applying), dan menalar (reasoning) seluruhnya sama, yaitu 1,00; (2) N-gain terendah elemen mengetahui, menerapkan, dan menalar berturut-turut sebesar $0,60,0,50$, dan 0,33 ; (3) $N$-gain rata-rata pada elemen mengetahui, menerapkan, dan menalar berturut-turut sebesar $0,91,0,75$, dan 0,73 ; (4) kategori peningkatan konsep pada elemen mengetahui yang berada kategori tinggi sebesar $93,33 \%$ dan sisanya berada pada kategori sedang; (5) kategori peningkatan konsep pada elemen menerapkan sebesar $60 \%$ berada pada kategori sedang dan sisanya berada pada kategori tinggi; dan (6) kategori peningkatan konsep pada elemen menalar sebesar $60 \%$ berada pada kategori sedang dan sisanya pada kategori tinggi. Keseluruhan hasil tersebut mengindikasikan bahwa intervensi yang dilakukan serta interaksi siswa selama proses pembelajaran dapat meningkatkan pemahaman konsep siswa pada tiap elemen pemahaman konsep dengan kategori sedang dan tinggi.

Jika $\mathrm{N}$-gain ditinjau dari total skor aspek kognitif pemahaman konsep dalam penelitian ini, yakni keutuhan penguasaan elemen mengetahui, menerapkan, dan menalar pada aspek secara lengkap maka sebaran data $\mathrm{N}$-gain dari total skor pemahaman konsep per individu dapat dideskripsikan sebagai berikut: (1) $\mathrm{N}$ gain individu tertinggi sebesar 1,00 ; (2) $N$-gain individu terendah sebesar dan 0,50 ; (3) $\mathrm{N}$-gain rata-rata sebesar 0,81 ; dan (4) persentase siswa yang mengalami peningkatan pema-haman konsep pada kategori tinggi $70 \%$ dan sisanya pada kategori sedang (lihat Gambar 2). Hasil ini memberikan informasi yang sama jika dibandingkan dengan $\mathrm{N}$-gain pada masing-masing elemen pemahaman konsep (elemen mengetahui, menerapkan, dan menalar), yaitu intervensi dan proses belajar dalam interaksi dapat meningkatkan pemahaman konsep siswa.

Hasil tersebut belum dapat menjelaskan alasan mengenai bervariasinya nilai $N$-gain yang diperoleh baik oleh masing-masing maupun rata-rata seluruh siswa setelah diberikan suatu intervensi tertentu. $\mathrm{N}$-gain memang memberikan banyak informasi penting tentang karakteristik perubahan skor dari hasil pretest dan posttest tetapi masih belum dapat menjelaskan beberapa skenario yang mungkin menyebabkan formula (nilai) $\mathrm{N}$-gain tidak dapat memberikan informasi yang cukup 
meyakinkan (Marx \& Cummings, 2007; Dellwo, 2010; Stewart \& Stewart, 2010; Smith et al., 2014). Oleh karena itu, $L$ digunakan untuk mempertimbangkan faktor retensi siswa pada proses transisi. $N$-gain dan $L$ memudahkan kita untuk memahami secara komprehensif mengenai dinamika pemahaman konsep siswa. Persentase transisi jawaban siswa dari hasil pretest dan posttest pemahaman konsep tentang energi untuk tiap elemen pemahaman konsep, disajikan pada Tabel 2.

Tabel 2. Persentase transisi jawaban siswa

\begin{tabular}{|l|l|l|l|l|}
\hline \multirow{2}{*}{$\begin{array}{l}\text { Elemen } \\
\text { Pemahaman } \\
\text { Konsep }\end{array}$} & \multicolumn{4}{|l|}{$\begin{array}{l}\text { Persentase transisi jawaban } \\
\text { siswa (\%) }\end{array}$} \\
\cline { 2 - 5 } & RR & WR & RW & WW \\
\hline $\begin{array}{l}\text { Mengetahui } \\
\text { (knowing) }\end{array}$ & 16,67 & 26,89 & 1,11 & 2,00 \\
\hline $\begin{array}{l}\text { Menerapkan } \\
\text { (applying) }\end{array}$ & 12,67 & 14,67 & 0,00 & 6,00 \\
\hline $\begin{array}{l}\text { Menalar } \\
\text { (reasoning) }\end{array}$ & 2,67 & 12,22 & 0,00 & 5,11 \\
\hline
\end{tabular}

Catatan:

$\mathrm{RR}=$ jawaban pada pretest dan posttest benar; WR = jawaban pada pretest salah dan pada posttest benar; RW = jawaban pada pretest benar dan pada posttest salah; dan $\mathrm{WW}=$ jawaban pada pretest dan posttest salah.

Hal yang menarik dari data pada Tabel 2 adalah persentase transisi RW tidak nol. Artinya, terjadi loss yang memengaruhi $\mathrm{N}$-gain siswa. Agar dapat menarik benang merah dari proses konstruktif (gain) dan destruktif (loss) pemahaman konsep siswa sebelum dan sesudah intervensi dan proses belajar dalam interaksi maka perlu untuk melihat kecenderungan $N$-gain per individu, nilai pemahaman konsep (penguasaan seluruh elemen pemahaman konsep), dan potensi loss yang ada pada setiap individu. Hasil nilai pemahaman konsep (pretest dan posttest), serta $L$ dan $N$-gain per individu siswa, disajikan pada Gambar 2.

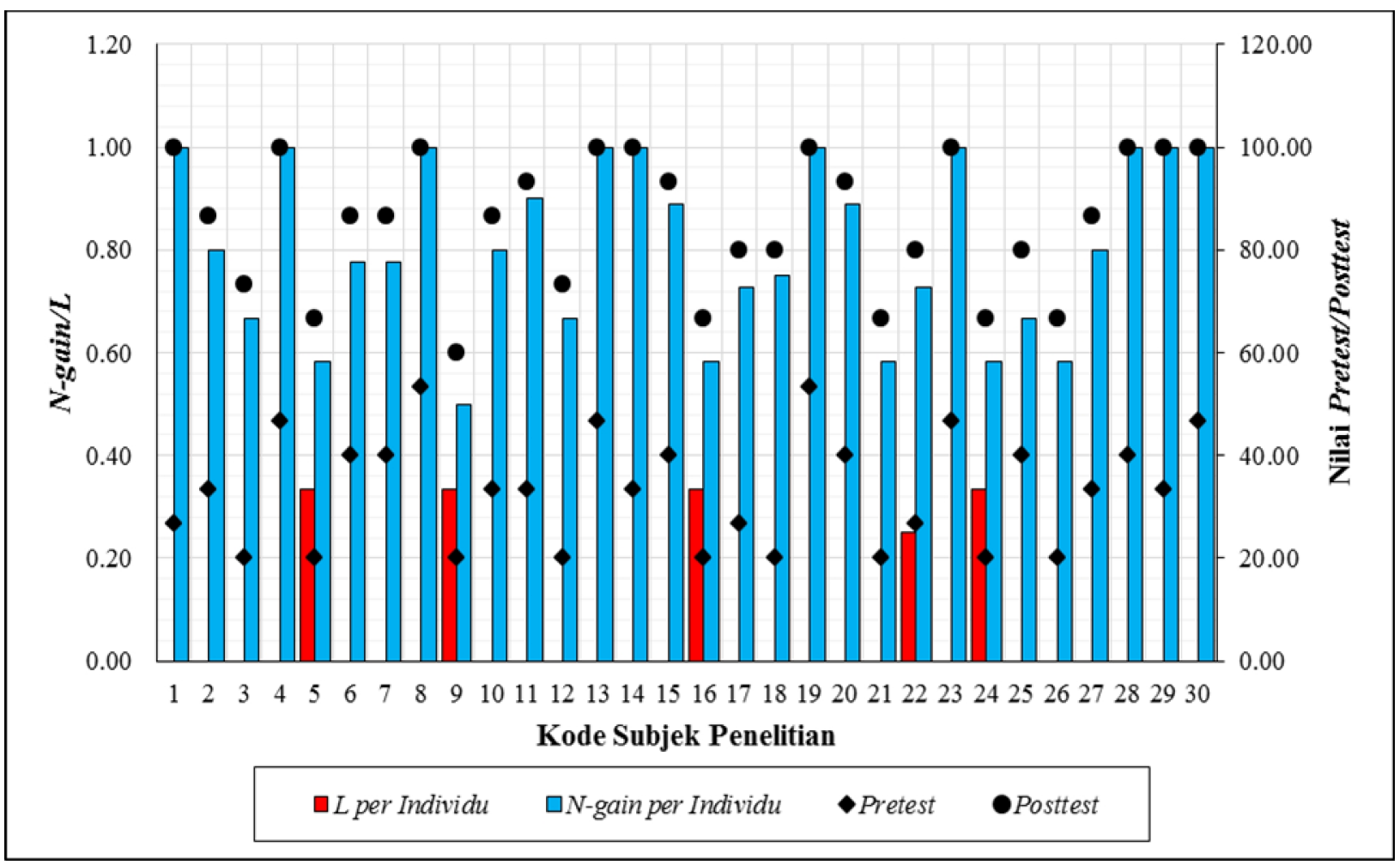

Gambar 2 Grafik sebaran data L dan N-gain perindividu yang mengacu pada nilai pretest/posttest pemahaman konsep

Gambar 2 tersebut mengungkapkan bahwa antara $N$ gain dan $L$ berbanding terbalik dan keduanya saling memengaruhi perolehan nilai hasil belajar aspek pemahaman konsep. Jika ditinjau dari sebaran nilai pretest dan posttest maka pada interval nilai yang rendah menunjukkan adanya nilai $L$ per individu dari seluruh subjek penelitian. Hal tersebut menginformasikan bahwa siswa dengan nilai pretest dan posttest yang rendah dipengaruhi oleh $L$, yaitu ada sebagian konsep yang loss dalam diri (kognisi) siswa dan proses transisi retensi (RR) atau gain siswa tidak terjadi. Nilai $L$ cenderung kecil sehingga $N$-gain (Hake's gain) dapat digunakan untuk menggantikan $G$ (Dellwo's gain) (Miller et al., 2010). Secara umum nilai $N$-gain $>L$, baik pada tiap elemen pemahaman konsep maupun secara individual. Hasil tersebut menunjukkan bahwa intervensi dan proses interaksi dalam proses pembelajaran mampu mengenalkan (to promote) siswa untuk belajar dan memperbaiki kekeliruannya selama PBM. 


\section{B. Pembahasan Hasil Penelitian}

Pemahaman konsep siswa selalu menjadi bagian yang tak terpisahkan dari tujuan pendidikan sains. Mempelajari dan menyelidiki bagaimana kita mengetahui suatu hal merupakan suatu kajian yang masih dilakukan sampai saat ini. Pemahaman konsep merupakan salah satu indikator untuk menjawab salah satu pertanyaan fundamental dan menjadi jantung perdebatan dalam bidang pendidikan yang telah disebutkan sebelumnya pada bagian Pendahuluan dalam artikel ini. Pemahaman konsep tidak dapat diukur langsung, melainkan hanya interpretasi dari hasil tes yang dilakukan oleh subjek penelitian. Salah satu penanda "keberhasilan" suatu intervensi (pembelajaran, program, dan lain sebagainya) yang berkembang dalam penelitian pendidikan fisika atau physics education research (PER) dan sekarang lazim digunakan hampir di seluruh bidang penelitian kependidikan adalah $\mathrm{N}$ gain yang telah ada sejak tahun 1949. Seiring perkembangan ilmu dan kajian terhadap N-gain dan segala skenario terhadap kelemahan formula $\mathrm{N}$-gain seperti yang dilakukan oleh Marx \& Cummings (2007), Bao (2006, 2008), Dellwo (2010), serta Stewart \& Stewart (2010). Hasil kajian para ahli tersebut dirujuk dalam artikel ini, yaitu dengan mengkaji perbandingan $N$-gain dan $L$ siswa sebagai indikator penentu dinamika pemahaman konsep siswa tentang energi.

Hasil kajian terhadap $N$-gain dan $L$ membawa dampak terhadap konsep $N$-gain dan $L$ itu sendiri. Miller et al. (2010) dan Lasry et al. (2014) yang mencoba untuk mengaitkan $N$-gain dan $L$ dengan peningkatan atau kehilangan pada level konseptual siswa karena suatu intervensi. Sebaran $N$-gain per individu dan tiap elemen pemahaman konsep menunjukkan perkembangan yang positif. Pemahaman konsep yang baik akan meningkatkan keterampilan pemecahan masalah (Fraser et al., 2014). Hal tersebut mengindikasikan bahwa siswa yang mendapatkan intervensi yang sesuai, akan memperoleh hasil belajar yang baik, karena memiliki kemampuan untuk menalar atas suatu masalah (reasoning) yang didukung dengan tingginya kapabilitas siswa pada proses akuisisi pengetahuan (knowing) dan menerapkan (applying) konsep-konsep substantif pada materi energi. Adanya transisi RW mengakibatkan ada siswa yang mengalami conceptual loss. Siswa yang mengalami loss tersebut cenderung memiliki $\mathrm{N}$-gain yang relatif lebih kecil jika dibandingkan siswa lain yang kami teliti (lihat Gambar 2). Kecenderungan tersebut sangat dipengaruhi oleh keyakinan epistemis dan siswa terhadap suatu hal yang dipelajarinya sehingga memengaruhi konsepsi siswa atas suatu konsep (representasi) sebagai bagian dari hubungan antara epistemologi, sosiologi, dan proses pembelajaran (Kim \& Song, 2010; Larsson \& Halldén, 2010; Sin, 2014). Faktor keyakinan tersebut dapat menyebabkan stabilitas maupun ketidakstabilan konsepsi yang siswa pelajari sehingga conceptual loss dapat terjadi.

Dinamika pemahaman konsep siswa ditinjau dari $\mathrm{N}$ gain dan $L$, perlu mempertimbangkan beberapa aspek penting yang melandasi formula $\mathrm{N}$-gain, yaitu: (1) pengukuran kemampuan belajar umum siswa; dan (2) independen terhadap pengetahuan awal siswa ( $N$-gain individu tidak berkorelasi dengan nilai/skor pretest) (Bao, 2008; Coletta et al., 2007). Hal tersebut mengindikasikan bahwa suatu intervensi dapat membawa efek positif atau efek negatif kepada siswa. Bao (2008) mengemukakan bahwa tiga tipe transisi pengetahuan siswa ditinjau dari proses kognitif yang memengaruhi pemahaman konsep karena suatu intervensi, yakni transisi tipe- $\alpha$, transisi tipe- $\beta$, dan transisi tipe- $\gamma$. Transisi tipe- $\alpha$ mencerminkan dampak langsung PBM (eksternal) secara langsung pada perubahan jawaban salah siswa, transisi tipe- $\beta$ mencerminkan dampak langsung PBM pada pengetahuan benar siswa, dan transisi tipe- $\gamma$ merefleksikan proses interaksi secara internal yang signifikan antara penge-tahuan yang benar dan salah. Seluruh tipe transisi tersebut dapat dilihat pada transisi jawaban siswa (Tabel 2).

Intervensi yang digunakan berupa model pembelajaran IIT dan artefak kependidikan yang mendukung siswa untuk belajar materi energi. Intervensi tersebut memfasilitasi terjadinya interaksi antara dalam belajar dan memediasi siswa untuk belajar. Interaksi antara siswa, guru, dan artefak memungkinkan siswa untuk belajar secara aktif. Intervensi yang bertumpu pada aktivitas berbasis inkuiri atau riset, memfasilitasi siswa untuk mengembangkan pengetahuannya pada level fenomena yang teramati dan level teori sehingga rata-rata $N$-gain pada tiap pemahaman konsep dan per individu berada pada kategori tinggi dan $L$ relatif kecil. Hal tersebut membuktikan bahwa pemahaman siswa akan berkembang ketika suatu intervensi yang diterapkan dalam suatu kelas menekankan pada kemampuan transfer dan inferensi bermakna atas konsep-konsep substantif, sehingga siswa secara efektif mampu menerapkannya pada kondisi yang beragam karena mampu menjadikan siswa untuk berpikir, yaitu kombinasi dari pengetahuan, keterampilan, dan sikap (Wecker et al., 2013; Orlich et al., 2010; Wiggins \& McTighe, 2005). Hasil studi juga mengungkapkan bahwa siswa yang berada pada kategori tinggi lebih dari $60 \%$, sehingga hal itu juga membuktikan bahwa kadang-kadang mayoritas siswa dalam suatu kelas akan mengonstruksi makna yang sama, dan makna tersebut akan mendekati cerminan dari makna yang diinginkan guru berdasarkan atensi, memori, berpikir, prosesproses internal, serta interaksi secara dialektis antara 
orang-orang dalam tiga ranah, yakni: kognitif, perilaku, dan emosional (Taber, 2011, Sternberg \& Williams, 2010; Santrock, 2011; Murphy, 2012). Fraser et al. (2014) juga telah mengingat-kan bahwa tidak selamanya intervensi berpengaruh terhadap diri siswa, walaupun sebagian besar intervensi yang dirancang berbasis siswa aktif itu lebih baik jika dibandingkan dengan PBM yang bersifat tradisional.

Adanya loss yang berhasil diungkap dalam studi ini semakin menegaskan bahwa pemahaman konsep siswa cenderung tidak linier perkembangannya. Hal tersebut menjawab mengapa rata-rata $\mathrm{N}$-gain yang dilaporkan dalam banyak studi sebelumnya tidak mencapai nilai maksimum karena munculnya loss tersebut. Hal tersebut disebabkan karena secara umum seseorang lebih berhasil untuk mendemonstrasikan pengetahuan ilmiahnya pada kondisi dan situasi tertentu dibandingkan beberapa situasi dan kondisi yang berbeda, beragamnya miskonsepsi siswa, serta tiap siswa juga mengembangkan pengetahuan secara personal (epistemological framing) yang unik dalam proses rekonstruksi pengetahuan dari guru pada proses pembelajaran yang kompleks (Taber, 2010, 2011; Lasry et al., 2014; Redish, 2014).

Munculnya $L$ tersebut juga membuktikan bahwa pemahaman konsep siswa dipengaruhi oleh interaksi dalam PBM dan pengetahuan terdahulu siswa. Hal tersebut juga selaras dengan temuan penelitianpenelitian terkini seperti Canu et al. (2016) dan Burgin \& Sadler (2016). Jika kita kaji data tampak beberapa orang siswa yang mengalami loss cenderung memperoleh $\mathrm{N}$-gain yang kecil atau rendah. Artinya, siswa dengan skor pretest yang rendah cenderung mengalami loss yang lebih tinggi dan hal tersebut membuktikan Matthew effect seperti hasil studi yang dilakukan oleh Miller et al. (2010) dan Lasry et al. (2014). Studi ini juga mengonfirmasi temuan Coletta et al. (2007), yaitu siswa yang memiliki $\mathrm{N}$-gain individu tinggi cenderung memiliki kemampuan menalar yang kuat.

Dinamika pemahaman konsep siswa yang terjadi karena adanya suatu intervensi berdasarkan perbandingan $\mathrm{N}$-gain dan $\mathrm{L}$ menunjukkan adanya mekanisme yang rumit dalam diri siswa untuk mengubah konsepsinya. Salah satu teori yang objek kajiannya adalah stabilitas dan/atau perubahan konsep, yakni teori perubahan konseptual (conceptual change). Teori perubahan konseptual dapat dibagi dalam tiga perspektif, yakni pandangan tradisional, pengetahuan seperti teori (PST), dan pengetahuan seperti elemen (PSE) (Vosniadou, 2007; Özdemir \& Clark, 2007). Hasil temuan pada studi ini mendukung perspektif PPSE karena salah satu ciri yang terbukti dari hasil studi ini selama proses intervensi pada classroom tryout bahwa siswa tidak serta-merta mengubah konsepsi sesuai dengan konsepsi yang disepakati oleh para ahli. Özdemir \& Clark (2007) juga menyatakan bahwa PPSE jauh lebih berguna untuk menjelaskan fase transisi dan fase koheren yang terjadi dalam perubahan konseptual seseorang.

Tidak dapat dimungkiri bahwa artikel ini mengandung kelemahan sehingga memengaruhi hasil analisis dan interpretasi data yang diperoleh. Pemahaman konsep dalam studi ini difokuskan dari pendekatan normative-positivistic. Selain itu, faktor shadow education, kultural, dan lingkup penelitian (demografis, non-demografis, lokasional, dan nonlokasional) juga sedikit banyak memengaruhi kesahihan hasil dan interpretasi yang tercantum dalam artikel ini. Studi ini juga berhasil memvalidasi salah satu perspektif dalam teori perubahan konsep khususnya pada materi energi serta menguak sedikit informasi tentang proses fluktuasi pemahaman konsep siswa akibat suatu intervensi tertentu, walaupun begitu pertanyaan fundamental yang disinggung di bagian Pendahuluan masih belum terjelaskan seluruhnya.

\section{KESIMPULAN}

\section{A. Simpulan}

Pemahaman konsep dan perubahan konsepsi siswa dipengaruhi oleh suatu intervensi tertentu dan semakin menguatkan teori perubahan konsep, khususnya pada perspektif PSE..

\section{B. Saran}

Agar dapat digeneralisasi dan dikembangkan menjadi suatu teori instruksional lokal maka studi ini perlu iterasi, replikasi, dan perbandingan dari berbagai classroom tryout untuk membuktikan validitasnya.

\section{REFERENSI}

Anderson, T.R., \& Schönborn, K.J. (2008). "Bridging the educational research-teaching practice gap: Conceptual understanding, part 1: The multifaceted nature of expert knowledge." Biochemistry and Molecular Biology Education, 36 (4), pp. $309-315$.

Bakker, A. (2004). Design Research in Statistics Education: On Symbolizing and Computer Tools (Published doctoral dissertation Utrecht University). Utrecht: CD- $\beta$ Press.

Bao, L. (2006). "Theoretical comparisons of average normalized gain calculations." American journal of physics, 74 (10), pp. $917-922$.

Bao, L. (2008). "Dynamic models of learning and education measurement." arXiv Cornell University Library. Retrieved from arXiv:0710.1375v2

Burgin, S.R., \& Sadler, T.D. (2016). "Learning nature of science concepts through a research 
apprenticeship program: A comparative study of three approaches." Journal of Research in Science Teaching, 53 (1), pp. 31 - 59.

Čančula, M.P., Planinšič, G., \& Etkina, E. (2015). “Analyzing patterns in experts' approaches to solving experimental problems." American Journal of Physics, 83 (4), pp. 366 - 374.

Canu, M., de Hosson, C., \& Duque, M. (2016). "Students' understanding of equilibrium and stability: The case of dynamic systems." International Journal of Science and Mathematics Education, 14 (1), pp. 101 - 123.

Clark, D.B., Menekse, M., Ozdemir, G., D’angelo, C.M., \& Schleigh, S.P. (2014). "Exploring sources of variation in studies of knowledge structure coherence: Comparing force meanings and force meaning consistency across two Turkish cities." Science Education, 98 (1), pp. $143-181$

Cobb, P., Confrey, J., diSessa, A., Lehrer, R., \& Schauble, L. (2003). "Design experiments in educational research." Educational Researcher, 10 (1), pp. 9-13.

Coca, D.M., \& Slisko, J. (2013). "The influence of active physics learning on reasoning skills of prospective elementary teachers: A short initial study with ISLE methodology." Latin American Journal of Physics Education, 7 (1), pp. $3-9$.

Coelho, R.L. (2009). “On the concept of energy: How understanding its history can improve physics teaching." Science and Education, 18 (8), pp. $961-983$.

Coelho, R.L. (2014). "On the concept of energy: Eclecticism and rationality." Science and Education, 23 (6), pp. 1361 - 1380.

Coffin, P. (2014). The Impact of Implementing Problem-Based Learning in a Thai University $\left(1^{\text {st }}\right.$ ed.). Department of Develpment and Planning, Aalborg University, Denmark.

Coletta, V.P., Phillips, J.A., \& Steinert, J.J. (2007, April). "Why you should measure your students' reasoning ability." The Physics Teachers, 49 (4), pp. 235 - 238.

Constantinou, C.P., \& Papadouris, N. (2012). "Teaching and learning about energy in middle school: An argument for an epistemic approach." Studies in Science Education, 48 (2), pp. $161-186$.

Delgado, C. (2015). "Navigating tensions between conceptual and metaconceptual goals in the use of models." Journal of Science Education and Technology, 24 (2-3), pp. 132 - 147.

Dellwo, D.R. (2010). "Course assessment using multistage pre/post testing and the components of normalized change." Journal of the Scholarship of Teaching and Learning, 10 (1), pp. $55-67$.

Ding, L., Chabay, R., \& Sherwood, B. (2013). "How do students in an innovative principle-based mechanics course understand energy concepts?" Journal of Research in Science Teaching, 50 (6), pp. $722-747$.

Dowd, J.E. (2012). Interpreting Assessments of Student Learning in the Introductory Physics Classroom and Laboratory (Unpublished doctoral dissertation). Harvard University, Massachusetts.

Duit, R. (2014). "Teaching and learning the physics energy concept.” In R.F. Chen, A. Eisenkraft, D. Fortus, J. Krajcik, K. Neumann, J.C. Nordine, \& A. Scheff. (Eds.). Teaching and Learning of Energy in K-12 Education, pp. 67 - 85. New York: Springer.

Fraser, J.M., Timan, A.L., Miller, K., Dowd, J.E., Tucker, L., \& Mazur, E. (2014). "Teaching and physics education research: Bridging the gap." Reports on Progress in Physics, 77 (3), 032401, pp. 1 - 17.

Garden, R.A., Lie, S., Robitaille, D.F., Angell, C., Martin, M.O., Mullis, I.V.S., Foy, P., \& Arora, A. (2006). TIMSS Advanced 2008: Assessment Frameworks. Chestnut Hill: TIMSS \& PIRLS International Study Center Lynch School of Education, Boston College.

Gott, R., \& Duggan, S. (1995). Investigative Work in the Science Curriculum. Buckingham: Open University Press.

Gravemeijer, K., \& Cobb, P. (2013). "Design research from the learning design perspective." In T. Plomp \& N. Nieveen (Eds.). Educational Design Research - Part A: An Introduction, pp. 73 - 113. Enschede: SLO.

Hake, H.R. (1998). "Interactive-engagement versus traditional methods: A six-thousand-student survey of mechanics test data for introductory physics courses." American Journal of Physics, 66 (1), pp. $64-74$.

Juuti, K., \& Lavonen, J. (2012). “Design-based research in science education: One step towards methodology." Nordic Studies in Science Education, 2 (2), pp. $54-68$.

Kelly, A.E., Baek, J.Y., Lesh, R. A., And BannanRitland, B. (2008). "Enabling innovations in education and systematizing their impact." In A. E. Kelly, R. A. Lesh, \& J. Y. Baek (Eds.). Handbook of Design Research Methods in Education: Innovations in Science, Technology, Engineering, and Mathema-tics 
Learning and Teaching, pp. $3-18$. New York: Routledge.

Kelly, G.J., \& Sezen, A. (2010). "Activity, discourse, \& meaning: Some directions for science education." In W.-M. Roth (Ed.). Re/Structuring Science Education: Reuniting Sociological and Psychological Perspec-tives, pp. 39 - 52. Dordrecht: Springer.

Ketpichainarong, W., Panijipan, B., \& Ruenwongsa, P. (2010). "Enhanced learning of biotechnology students by an inquiry-based cellulase laboratory." International Journal of Environmental \& Science Education, 5 (2), pp. $169-187$.

Kim, M., \& Song, J. (2010). “A confirmatory structural equation model of achievement estimated by dichotomous attitudes, interest, and conceptual understanding." Eurasia Journal of Mathematics, Science \& Technology Education, 6 (4), pp. $271-285$.

Kind, P.M. (2013a). "Conceptualizing the science curriculum: 40 years of developing assessment frameworks in three large-scale assessments." Science Education, 97 (5), pp. 671 - 694.

Kind, P.M. (2013b). "Establishing assessment scales using a novel disciplinary rationale for scientific reasoning." Journal of Research in Science Teaching, 50 (5), pp. $530-560$.

Larsson, Å. and Halldén, O. (2010). "A structural view on the emergence of a conception: Conceptual change as radical reconstruction of contexts." Science Education, 94 (4), pp. 640 - 664.

Lasry, N., Guillemette, J., \& Mazur, E. (2014). "Two steps forward, one step back." Nature Physics, 10 (6), pp. $402-403$.

Lee, H.-S., \& Liu, O.L. (2010). "Assessing learning progression of energy concepts across middle school grades: The knowledge integration perspective." Science Education, 94 (4), pp. $665-688$.

Marx, J.D., \& Cummings, K. (2007). "Normalized change." American Journal of Physics, 75 (1), pp. $87-91$.

Miller, K., Lasry, N., Reshef, O., Dowd, J., Araujo, I., \& Mazur, E. (2010, October). "Losing it: The influence of losses on individuals' normalized gains." AIP Conference Proceedings, 1289 (1), pp. $229-232$.

Murphy, C. (2012). "Vygotsky and primary science." In B.J. Fraser, K.G. Tobin, \& C.J. McRobbie (Eds.). Second International Handbook of Science Education, pp. 177 - 188. Dordrecht: Springer.

Niss, M. (2012). "Towards a conceptual framework for identifying student difficulties with solving real-world problems in physics." Latin American Journal of Physics Education, 6 (1), pp. $3-13$.

NRC. (2012). A Framework for K-12 Science Education: Practices, Crosscutting Concepts, and Core Ideas. Committee on a Conceptual Framework for New K-12 Science Education Standards. Board on Science Education, Division of Behavioral and Social Sciences and Education. Washington, DC: The National Academies Press.

Orlich, D.C., Harder, R.J., Callahan, R.C., Trevisan, M.S., \& Brown, A.H. (2010). Teaching Strategies: A Guide to Effective Instruction $\left(9^{\text {th }}\right.$ edition). Boston: Wadsworth, Cengage Learning.

Özdemir, G., \& Clark, D.B. (2007). "An overview of conceptual change theories." Eurasia Journal Of Mathematics, Science \& Technology Education, 3 (4), pp. 351 - 361.

Redish, E.F. (1994). "Implications of cognitive studies for teaching physics." American Journal of Physics, 62 (9), pp. $796-803$.

Redish, E.F. (2014). "Oersted lecture 2013: How should we think about how our students think?" American Journal of Physics, 82 (6), pp. $537-551$.

Rusli, A. (2012, June). "Science and scientific literacy vs science and scientific awareness through basic physics lectures: A study of wish and reality." AIP conference proceedings, 1454 (1), pp. $169-173$.

Santrock, J.W. (2011). Educational Psychology (5 ${ }^{\text {th }}$ edition). New York: McGraw-Hill.

Scott, T.D., Hazari, Z., \& Potvin, G. (2013). "Interdisciplinary thinking and physics identity." In P.V. Engelhardt, A.D. Churukian, \& D.L. Jones (Eds.). 2013 Physics Education Research Conference Proceedings, pp. 329 332. Portland: American Association of Physics Teachers (AAPT) \& Physics and Astronomy Education Communities (comPADRE).

Sin, C. (2014). "Epistemology, sociology, and learning and teaching in physics." Science Education, 98 (2), pp. $342-365$.

Singh, C., \& Rosengrant, D. (2003). "Multiple-choice test of energy and momentum concepts." American Journal of Physics, 71 (6), pp. 607 617.

Smith, T.I., Wittmann, M.C., \& Carter, T. (2014). "Applying model analysis to a resource-based analysis of the force and motion conceptual evaluation." Physical Review Special Topics - 
Physics Education Research, 10 (2), 020102, pp. $1-17$.

Sternberg, R.J., \& Williams, W.M. 2010. Educational Psychology ( $2^{\text {nd }}$ edition). Upper-Saddle River: Pearson/Merril.

Stewart, J., \& Stewart, G. (2010, March). "Correcting the normalized gain for guessing." The Physics Teacher, 48 (3), pp. 194 - 196.

Taber, K.S. (2010). "Intuitions, conceptions and frameworks: Modelling student cognition in science learning." In M.S. Khine \& I.M. Saleh (Eds.). New Science of Learning: Cognition, Computers and Collaboration in Education, pp. 163 - 182. Dordrecht: Springer.

Taber, K.S. (2011). "Constructivism as educational theory: Contingency in learning, and optimally guided instruction." In J. Hassaskhah (Ed.). Educational Theory, pp. 39 - 61. New York: Nova Science Publishers.

Vosniadou, S. (2007). "The conceptual change approach and its re-framing." In S. Vosniadou, A. Baltas, \& X. Vamvakoussi (Eds.). Reframing the Conceptual Change Approach in Learning and Instruction, pp. $1-16$. Amsterdam: Earli.
Wang, F., \& Hannafin, M. J. (2005). "Design-based research and technology-enhanced learning environments." Educational Technology, Research and Development, 53 (4), pp. 5 - 23.

Wecker, C., Rachel, A., Heran-Dörr, E., Waltner, C., Wiesner, H., \& Fischer, F. (2013). "Presenting theoritical ideas prior to inquiry activities fosters theory-level knowledge." Journal of Research in Science Teaching. 50 (10), pp. $1180-1206$.

Wiggins, G., \& McTighe, J. (2005). Understanding by Design (Expanded $2^{\text {nd }}$ edition). Virginia: ASCD. 